
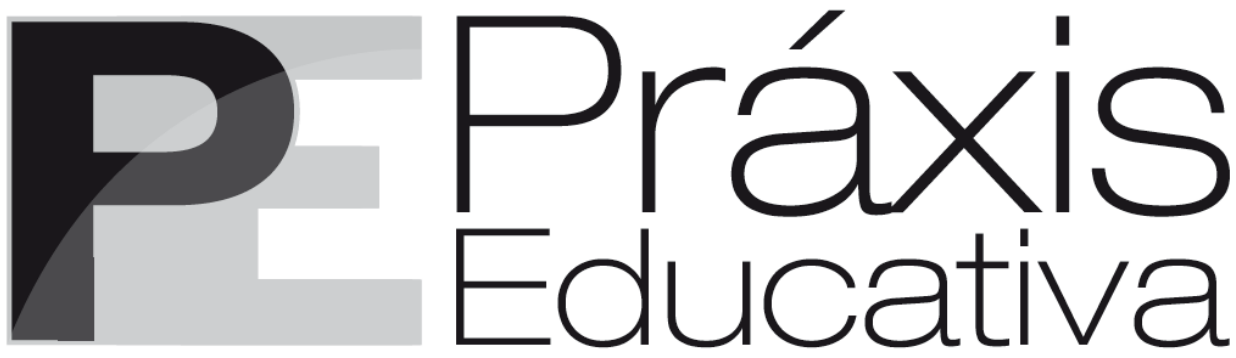

ISSN 1809-4031

elSSN 1809-4309

http://dx.doi.org/10.5212/PraxEduc.v.14n3.006

\title{
As muitas Evas de uma história: a produção de um lugar a partir da publicação de autobiografias no campo religioso protestante ${ }^{*}$
}

\section{The many Evas of a story: the production of a place from the publication of autobiographies in the Protestant religious field}

\section{Las muchas Evas de una historia: la producción de un lugar a partir de la publicación de autobiografías en el campo religioso protestante}

\author{
Loyde Anne Carreiro Silva Veras ${ }^{* *}$ \\ Evelyn de Almeida Orlando ${ }^{* *}$
}

Resumo: Este artigo é uma análise do projeto autobiográfico de Eva Yarwood Mills (1903-1987) a partir das relações de gênero presentes nas suas obras. Buscou-se questionar quais representações Eva Mills construiu de si por meio das representações de outras mulheres e dos papéis negociados pela autoranarradora-personagem em ambiente religioso protestante. Este recorte de pesquisa dialoga e contribui, a partir da Histórica Cultural, com os campos dos Estudos (auto)biográficos, da História das Mulheres, da História das Religiões e da História da Educação (educação protestante). Operou-se com conceitos como representação, memória e identidade, tradução cultural e processo civilizador. Verificou-se um processo de construção de identidade de uma professora em íntima relação e negociação com as exigências de seu grupo de pertencimento, tanto no tempo dos fatos memorados quanto no tempo da escrita memorialística.

Palavras-chave: Autobiografia. Memória e identidade. Educação protestante.

Abstract: This paper is an analysis of the autobiographical project of Eva Yarwood Mills (1903-1987) from the gender relations present in the works of this author. It searches to question which representations Eva Mills constructed of herself through the representations of other women and of the roles negotiated by the author-narrator-character in the protestant religious context. This research cutoff dialogues and contributes, starting from the Cultural History, with the fields of (Auto)biographical studies, History of Women, History of Religions and History of Education (Protestant education). This analysis

\footnotetext{
* Esta pesquisa faz parte do projeto "Educação, Gênero e Cristianismo: circulação, representação, formação e práticas femininas em cenário religioso e educativo", sob coordenação da Profa. Dra. Evelyn de Almeida Orlando, financiado pelo Edital Universal CNPq/ 2016 e com bolsa CAPES.

** Doutoranda em Educação pela Pontifícia Universidade Católica do Paraná - PUCPR. E-mail: loydeanne08@gmail.com. ORCID: https://orcid.org/0000-0001-7755-2434

*** Professora da Escola de Educação e Humanidades e do Programa de Pós-Graduação em Educação da Pontifícia Universidade Católica do Paraná - PUCR. E-mail: evelynorlando@gmail.com. ORCID: https://orcid.org/00000001-5795-943X
} 
As muitas Evas de uma história: a produção de um lugar a partir da publicação de autobiografias...

worked with concepts such as representation, memory and identity, cultural translation and the civilizing process. It was found a process of identity construction of a teacher in close relation and negotiation with the demands of her group of belonging, both in the time of the memorized facts and in the time of the memorialistic writing.

Keywords: Autobiography. Memory and identity. Protestant education.

Resumen: Este artículo es un análisis del proyecto autobiográfico de Eva Yarwood Mills (1903-1987) a partir de las relaciones de género presentes en sus obras. Se buscó cuestionar cuáles representaciones Eva Mills construyó de si, por medio de las representaciones de otras mujeres y de los papeles negociados por la autora-narradora-personaje en ambiente religioso protestante. Este recorte de investigación dialoga y contribuye, desde la Histórica Cultural, con los campos de los Estudios (auto)biográficos, de la Historia de las Mujeres, de la Historia de las Religiones y de la Historia de la Educación (educación protestante). Se trabajó con conceptos como representación, memoria e identidad, traducción cultural y proceso civilizador. Se verificó un proceso de construcción de identidad de una profesora en estrecha relación y negociación con las exigencias de su grupo de pertenecimiento, tanto en el tiempo de los hechos recordados, como en el tiempo de la redacción memorialista.

Palabras clave: Autobiografía. Memoria e identidad. Educación protestante.

\section{Introdução}

Eu vim para esta bela casa de aposentados para cristãos em abril de 1974. A bela quietude que me cerca, o carinho da equipe cristã, a amizade entre os residentes da casa, fez minha visão para escrever um livro de louvor tornar-se realidade.

Agora, do ponto de vista privilegiado da Terra de Beulá, eu olho para trás, para a trilha da selva da vida e vejo muito mais claramente todo o caminho que o Senhor me levou através de veredas espinhosas, lugares difíceis e desafios tempestuosos.

(EVA MILLS, 1976, p. 132, tradução nossa) ${ }^{1}$.

Esse fragmento autobiográfico, extraído de um dos livros de Eva Yarwood Mills (19031987), descreve o lugar onde a autora estava quando produziu as escritas de si. Ela, uma inglesa que trabalhou no Brasil por mais de 30 anos como professora-missionária-protestante no interior "primitivo" do Norte do Brasil (MILLS, 1976), se aposentou nos Estados Unidos, vindo a se recolher no Calvary Fellowship Homes, em Lancaster, Pensilvânia ${ }^{2}$.

\footnotetext{
1 "I came to this beautiful retirement home for Christians in April 1974. The quiet beauty surrounding me, the kindness of the Christian staff, the fellowship of kindred minds among the residents, made the vision of writing a book of praise become a reality. [...] Now, from the vantage point of Beulah Land, I look back along the jungle trail of life and see much more clearly all the way the Lord has led me through thorny paths, difficult places and stormy challenges."

${ }^{2}$ Eva Mills foi morar nesse asilo após ter sido diagnosticada com Leucemia no ano de 1974. O tempo que esteve ali foi marcado pela dura evolução dessa enfermidade, levando-a à morte em 1986. Sua opção pelos Estados Unidos em detrimento da Inglaterra, sua terra natal, deveu-se aos laços e à rede de sociabilidade construída em continente norteamericano no período pós Segunda Guerra Mundial (VERAS, 2017).
}

Práxis Educativa, Ponta Grossa, v. 14, n. 3, p. 915-937, set./dez. 2019 Disponível em: <http://www.revistas2.uepg.br/index.php/praxiseducativa> 
Em sua estada nesse asilo, Eva Mills produziu textos, escreveu cartas e publicou três livros: o 8:28, uma autobiografia publicada no ano de 1976 3 ; Em lugar do espinheiro, produzido em português e enviado para o Brasil, por volta do ano de 1982; e o Stories from parakeet country (1986), com histórias em formato de crônicas para crianças e adolescentes. Este último estava identificado como "vol. 1", e o que viria a ser o segundo volume ficou organizado em manuscritos, sem publicação impressa ${ }^{4}$.

Em tempo de olhar para trás, para a "trilha da selva da vida", como citado na epígrafe, sua memória evidenciou um novo faz̧er (BOSI, 2004) nessas três obras, compondo aquilo que identificamos como o projeto autobiográfico de sua velhice. No percurso de análise desses livros, entendemos as representações e as autorrepresentações de Eva Mills postuladas em seus livros como "[...] esquemas intelectuais incorporados que criam as figuras graças às quais o presente pode adquirir sentido, o outro tornar-se inteligível e o espaço ser decifrado" (CHARTIER, 1990, p. 17).

Consideramos também que as seleções sobre qual história narrar, como contar ou para quem escrever não foram feitas ao acaso e revelam a posição no campo que a autora procurou ocupar. Dessa forma, ao construir uma memorialística sobre si, Eva Mills também o fez sobre um outro, como "[...] elemento constituinte do sentimento de identidade" de grupo (POLLAK, 1992). Memória e identidade, como disse Pollak (1992, p. 204), “[...] podem perfeitamente ser negociadas, e não são fenômenos que devam ser compreendidos como essências de uma pessoa ou de um grupo", mas construídos.

A partir desses preceitos, interessou-nos questionar quais representações Eva Mills construiu de si no projeto autobiográfico, com a finalidade de identificar e analisar os papéis produzidos pela autora-narradora-personagem (LEJEUNE, 2008) a partir das relações de gênero presentes em suas obras e, ainda, o modo como esses papéis foram operados em ambiente religioso protestante.

Esse trabalho contribui e dialoga com três linhas de investigação no campo da História da Educação: Estudos (Auto)biográficos, Educação Protestante e História das Mulheres. Nesse entrecruzamento, pesquisas como as de Mignot (2002), Mignot e Cunha (2003), Souza e Passeggi (2011), Silva (2014), entre outras, evidenciam um olhar mais atento às (auto)biografias, especialmente as de professores(as) como fontes importantes que permitem apreender os muitos caminhos da história da formação e da profissão docente. Outros autores, como Hilsdorf (1986, 2002), Mesquida (2016), Mesquida e Ferreira (2015), Chamon (2005, 2006) e Nascimento (2007), salientam a presença de mulheres-professoras por meio da ação de missões protestantes no Brasil na virada do século XIX para o XX. Nesse artigo, o diálogo com Perrot (2016), Beauvoir (1980), Silva $(1998,2015)$ e Seiguer (2015) foi especialmente importante para a compreensão do espaço da mulher e suas representações dentro do ambiente protestante sobre o qual Eva Mills se construiu.

\footnotetext{
${ }^{3}$ O 8:28 foi traduzido para o português e publicado no Brasil em julho de 2017 pela editora Literatura Cristã Evangélica. Todavia, vale a ressalva que utilizamos, para a presente análise do material, a fonte original em inglês de 1976. É essa a versão do livro que se encontra neste artigo, tradução realizada pelas autoras e com o texto original em nota de rodapé, assim como feito com os demais. A justificativa não se funda em uma recusa da tradução, mas por se tratar de um estudo anterior à nova publicação.

${ }^{4}$ Eva Mills faleceu antes do encaminhamento deste material para publicação, ficando guardado no arquivo pessoal da família.
}

Práxis Educativa, Ponta Grossa, v. 14, n. 3, p. 915-937, set./dez. 2019 Disponível em: <http://www.revistas2.uepg.br/index.php/praxiseducativa> 
As muitas Evas de uma história: a produção de um lugar a partir da publicação de autobiografias...

Os livros de Eva Mills, com estilos e públicos distintos, foram marcados por uma escrita autobiográfica a partir de elementos de uma vida autoral construída no Brasil, completando-se em múltiplos sentidos. As representações sociais construídas, por Eva Mills, de si e de outras mulheres dizem de uma única construção identitária - a da autora - mas sob aspectos diferenciados. Uma única mulher em diferentes matizes. Em cada um dos livros, a "esposa de missionário", a "missionária" e a "professora" são desvendadas.

Na primeira parte deste artigo, abordamos o que seria, para a autora e seu grupo religioso protestante, a representação de um perfil ideal de mulher: Eva Mills como uma esposa de um missionário e, com ela, representações de mulheres como boas esposas e mães. Na segunda parte, seguindo as publicações do segundo e terceiro livros, percebemos a construção identitária de Eva Mills como uma missionária e professora (em distinção à figura da esposa), fundada a partir de representações de si e de outras mulheres, na vida privada ou pública dentro do ambiente religioso. Por fim, discutimos as muitas Evas de uma vida, sob a óptica das relações de gênero experienciadas pela autora-narradora-personagem nessas (auto)biografias.

\section{Um perfil ideal? Eva, esposa de missionário}

O primeiro livro publicado por Eva Mills - o 8:28 - é sua autobiografia, sua “[...] narrativa retrospectiva em prosa que uma pessoa faz de sua própria existência, quando focaliza sua história individual" (LEJEUNE, 2008, p. 16). Nesse livro, Eva Mills é autora, narradora e personagem da narrativa. É nesse espaço que encontramos em evidência a trajetória de uma Eva "esposa de missionário". Contudo, antes de prosseguirmos às evidências dessa representação, importante explicar o termo em destaque.

Temos percebido, tanto nas fontes quanto na historiografia protestante, uma distinção de categoria entre a "missionária" - atribuída a mulheres solteiras que desenvolveram seu trabalho independente da figura masculina, ou seja, de um marido -, e a "esposa de missionário". Esta, independentemente de suas funções fora do lar e de também ser considerada missionária, tem sua biografia construída a partir da figura do marido, sobre as representações de esposa, auxiliar do marido, dona de casa, mãe, cuidadora, educadora, a partir dos referenciais de uma mulher burguesa do século XIX

O perfil biográfico de Eva Mills, em 8:28, condiz com a segunda representação. Desde o início dos relatos, Eva Mills discorre sobre sua chamada vocacional em vir para o Brasil, alimentada em cumplicidade com David Mills, seu futuro marido. Ela narra sua vinda, a fim de se encontrar com o noivo, e o casamento em língua e ritos estranhos à sua própria cultura.

Eva Mills então perfaz sua "ilusão retórica" (BOURDIEU, 1996) nos 11 primeiros anos de trabalho no Brasil. Descreve seu processo de adaptação cultural, seus estranhamentos e como vai se acomodando ao país, especialmente na relação com as mulheres, sua inserção no campo educacional de forma gradual até se assumir como professora e diretora de escolas. Contudo, há uma quebra no ritmo da narrativa quando a autora-personagem chega no evento da separação do casal Mills; ela praticamente conclui o livro nesse ponto. A partir de então, o tempo narrativo de sua vida no Brasil é acelerado, e o período seguinte ao fato é comprimido em um único capítulo, finalizando assim a autobiografia. Essa quebra na narrativa é sintomática dos conflitos

\footnotetext{
5 Paula Seiguer (2015) faz uma análise muito interessante tomando por base as distinções de "esposas" e "outras mulheres", expressões extraídas de um relatório estatístico sobre missões protestantes na América Latina, publicado por Beach em 1900. Seiguer desenvolve sua análise com biografias de mulheres missionárias na perspectiva de elucidar os diferentes espaços ocupados por mulheres nas missões protestantes. Sobre mulheres e as diferentes ações desenvolvidas em grupos protestantes no Brasil, ver Elizete da Silva (1998, 2015).
}

Práxis Educativa, Ponta Grossa, v. 14, n. 3, p. 915-937, set./dez. 2019 Disponível em: <http://www.revistas2.uepg.br/index.php/praxiseducativa> 
enfrentados entre os papéis sociais e religiosos aceitos, requeridos e os (não)vividos por ela, como mulher, especialmente no papel de esposa.

A rememoração autobiográfica de $8: 28$, sob o ponto de vista de uma "esposa de missionário", possibilitou a construção de uma narrativa sob uma perspectiva singular: o ambiente doméstico e o acesso à intimidade dos lares. É aqui que seu ofício como visitadora de lares aparece, trabalho que objetivava por meio da conquista das mulheres: o acesso aos demais membros da família (homens) em ambiente público, papel atribuído aos homens do grupo.

Conquanto, é importante salientar que, em suas narrativas, Eva Mills nunca esteve enclausurada em seu próprio ambiente privado. Ela sempre se figurou em ação no ambiente público a partir do acesso ao ambiente privado de outrem e da relação com outras mulheres. $\mathrm{O}$ acesso ao mundo privado das famílias trouxe, às narrativas da Mills, as percepções do cotidiano familiar, do trabalho doméstico e de suas expectativas e dilemas. Isso não é por acaso, principalmente quando considerado que ela mesma estava inserida nas relações de disputa de representações entre seus pares, em um espaço eminentemente masculino, como o campo religioso do qual ela fez parte.

Os "nossos homens", como Eva Mills se referia a David Mills e Donald Monteith", falavam no espaço público, enquanto elas, Eva e Vera, as esposas, tentavam se comunicar com as mulheres da casa. "Tentavam", pois nem sempre conseguiam, dados os entraves no processo de comunicação com a cultura local, não somente com a questão da diferença linguística:

Em Imperatriz, o trabalho estava crescendo e as visitas estavam ocupando muito tempo. Eu fiquei encantada quando, um dia, Perpétua Sampaio decidiu que gostaria de fazer visitação comigo. [...] eu me senti muito em casa com ela, agradecida pela boa relação espiritual e pelo perfeito guiar dela sobre os costumes e etiquetas do interior. Ela sabia como se aproximar das mulheres e, é claro, sua linguagem era muito fluente e fácil de entender. Ao entrar na casa dos descrentes, Perpétua assumia a liderança, conversava sobre a família, seus interesses, trabalho, saúde e conduzia a uma conversa descontraída sobre as mulheres, que eram o objeto de nosso interesse específico. Quando a conversa já havia evoluído bastante, ela, de forma inteligente, me perguntava alguma questão ou fazia uma observação que me dava a oportunidade para adentrar questões espirituais. O costume britânico de ser brusco e objetivo, indo diretamente ao ponto central da questão, não agradava aos brasileiros, que consideravam isso uma grosseria. Aprendi muito nas visitações com Perpétua ${ }^{7}$. (MILLS, 1976, p. 67, tradução nossa).

Percebendo-se leiga nos costumes e nas etiquetas do interior brasileiro, Eva Mills reconheceu que seus costumes britânicos não condiziam com a maleabilidade exigida por aquelas brasileiras, um empecilho para de fato entrar em suas casas. Em episódios como esse, Eva Mills desnuda parte do processo de aprendizagem e adaptação cultural, revelando suas negociações à

\footnotetext{
${ }^{6}$ Nos primeiros anos de missão no Brasil, no interior do Maranhão, Eva e David Mills trabalharam com outro casal de missionários, os australianos Donald e Vera Monteith.

7 "In Imperatriz, the work was growing and visitation was occupying much time. I was delighted, one day, when Perpetua Sampaio decided she would like to do visitation with me. [...] I felt so much at home with her, thankful for good spiritual relationship and at perfect ease in her guidance regarding interior customs and etiquette. She knew how to approach the women, and, of course, her language was so fluent and easy to understand. Entering the home of unbelievers, Perpetua took the lead, talked about the family, its interests, work and health and drew into easy conversation the women, who were the objects of our special interest When the time was ripe, she would cleverly ask me a question or make a remark that gave me the lead in spiritual matters. The British custom of being blunt and outspoken, going straight to the point of our interest, does not please the Brazilian, who considers this rudeness. I learned much from visitation with Perpetua."
}

Práxis Educativa, Ponta Grossa, v. 14, n. 3, p. 915-937, set./dez. 2019 Disponível em: <http://www.revistas2.uepg.br/index.php/praxiseducativa $>$ 
As muitas Evas de uma história: a produção de um lugar a partir da publicação de autobiografias...

nova cultura ${ }^{8}$. Aquilo que era considerado, na cultura inglesa, uma boa etiqueta ao iniciar uma conversa com alguém, entre aquelas mulheres era tido como uma atitude grosseira. Sem a intervenção e a ajuda de Perpétua, ela talvez sequer teria percebido, ou demorado a perceber, alguns pontos que acentuavam o choque cultural vivenciado por ambos os lados.

A iniciativa de Perpétua Sampaio em participar dos trabalhos de visitação deu um novo fôlego ao trabalho de Eva Mills, pois, além de dominar a língua portuguesa, ela manejava bem o processo de sociabilização local entre as mulheres (porque também era uma delas, uma nativa), o que serviu de estratégia no estabelecimento dos contatos e no acesso às casas e aos locais. Perpétua foi sua parceira de evangelização por muito tempo, inclusive quando Eva Mills se mudou de Imperatriz para Balsas, ambos municípios do Maranhão (MA).

Nesse capítulo de sua história, as mulheres com as quais Eva Mills trabalhava foram identificadas como audazes, ativas, participando em todo o processo de consolidação do grupo protestante que se formava. Não só por enfrentarem a família, mas também por terem iniciativa na propagação da mensagem protestante a partir de seus eixos de sociabilidade, como Maria Piauí, que viajava sozinha de jumento para compartilhar as bem-aventuranças aos familiares em outras vilas (viagens como esta demoravam semanas pela mata densa). Ou mesmo o envolvimento maciço das mulheres no trabalho prático de construção do templo em Imperatriz, como Maria Mercedes, que se responsabilizou pela fabricação dos tijolos usados no novo prédio, e Maria Piauí, que se dispôs a carregá-los.

Os relatos de Eva Mills dão conta da ação dessas mulheres e da sua participação ativa na construção e na consolidação de uma identidade de grupo, com atenção especial aos processos de conversão. As mulheres que assumiam a nova vida são representadas em suas mudanças de comportamentos e de sensibilidades, por meio de cuidados com a higiene do próprio corpo, uso de roupas limpas e cabelos penteados. Essas mudanças condizem com as mudanças de comportamento consideradas típicas no "processo civilizador" analisadas por Norbert Elias (1994), mediante o qual o grupo protestante de Eva Mills estava construindo sua própria identidade de grupo, ou seja, identificando a imagem dos protestantes a uma perspectiva tida como padrão de civilidade ocidental, em que ela mesma, uma inglesa, era o modelo. Mudanças requeridas como testemunho público, em outras palavras, uma forma de visibilizar e distinguir uma identidade de grupo diante de outros grupos.

O interesse pela aprendizagem da leitura e da escrita também viria como consequência da conversão ao protestantismo. Para Eva Mills, educação e religião faziam parte de uma natureza que trabalha na transformação de um ambiente ou de uma realidade. Isso poderia e deveria ser dado a ver no próprio corpo, nos hábitos e nos comportamentos, como indícios da regulação do indivíduo por meio de suas condutas.

\footnotetext{
${ }^{8}$ Estes desnudamentos no processo de adaptação cultural também configuram um processo de "tradução cultural" para aqueles que iriam ler os livros, especialmente estadunidenses, mas também britânicos, canadenses, australianos, suíços, alemãs etc. Esse alcance deu-se devido às origens étnicas dos missionários vinculados à Unevangelized Field Missions - UFM - e empresas missionárias parceiras. Entendemos tradução cultural no sentido operado por PallaresBurke (1996), uma ação consciente em compreender e decifrar a cultura do outro. Para ela, “[...] a recepção de uma cultura por outra exige, pois, que ela seja 'traduzida' por um intermediário, um intérprete que se esforça conscientemente em tornar seus caracteres e sua linguagem compreensíveis a 'leitores' habituados a outros 'textos"” (PALLARES-BURKE, 1996, p. 14).
}

Práxis Educativa, Ponta Grossa, v. 14, n. 3, p. 915-937, set./dez. 2019 Disponível em: <http://www.revistas2.uepg.br/index.php/praxiseducativa> 
Maria Piauí pertencia a uma família pobre de agricultores e nunca aprendeu a ler. Ela tinha, então, mais de trinta anos, aleijada por causa de doença, mas era entusiasmada. Todos os dias ela vinha, aprendia rapidamente, memorizava várias partes da Escritura, sua alegria no Senhor apenas crescia e, ao mesmo tempo, nos dava grande alegria. Em vez da velha Maria, suja e despenteada, agora víamos Maria andando pela rua com um rosto radiante, roupas limpas e cabelo penteado, além de sua Bíblia embaixo do braço. Ela ia em direção aos seus antigos companheiros de pecado. Eles zombavam e a chamavam de hipócrita por carregar uma Bíblia quando eles sabiam que ela não sabia ler. Ela abria sua Bíblia e lia uma passagem que havia memorizado, indicando com o dedo cada palavra, lentamente. Eles ficavam maravilhados?. (MILLS, 1976, p. 44, tradução nossa).

Eva Mills mostra-se sensível a essas mulheres e impactada com o que o ato de aprender a ler, ou até mesmo fingir ler, e carregar com orgulho um livro debaixo do braço era capaz de fazer com a autoestima - "[...] agora víamos Maria andando pela rua com um rosto radiante, roupas limpas e cabelo penteado" - a ponto de suportar com ousadia as investidas de um grupo zombeteiro.

O modus protestante de Eva Mills envolvia o ensinamento da moral cristã, cuja base está na leitura de um livro, e a alfabetização era a condição necessária para viabilizar uma efetiva mudança de vida. O livre acesso às Sagradas Escrituras, fundamento protestante que apregoa que todos possam ler a Bíblia, requeria, consequentemente, para Eva Mills, que todos tivessem acesso ao poder de ler (CASTILLO GÓMEZ, 2003), daí a simples esperança de acesso à educação já ser capaz de trazer alguma expectativa de transformação social.

[...] meu coração ia ao encontro daquelas mulheres escondidas e esquecidas, escravas, da manhã até a noite, de uma panela de ferro sobre um fogão feito no chão de barro. Esse fogo era mantido no lugar por três grandes pedras, sobre as quais a panela descansava, e a fumaça espiralada da lenha que queimava encontrava seu caminho até os olhos das crianças, que seguravam abanos de folhas de palmeira para manter a chama viva, e então seguia rumo ao teto de folhas já escurecidas, da melhor maneira que conseguia até escapar da cabana. De tempos em tempos, a mãe mexia o feijão com uma grande concha ou espátula de madeira. Às vezes, nos fundos da casa, esta mulher ia socar o milho que havia colhido e transportado de seu pequeno lote de terra a alguma distância de casa. Às vezes, na margem do rio, ela agachava-se e batia as roupas bem ensaboadas em uma tábua ou, se não, numa pedra. Às vezes, no quarto mal iluminado de sua casa, passava o pesado ferro fumegante, cheio de brasas brilhantes de fogo, sobre as roupas de algum funcionário da cidade, e o suor e a fumaça misturavam-se ao seu desgastado vestido de algodão quando ela enxugava o rosto para aliviar o calor. As moscas, o calor, a pobreza e os outros desconfortos eram seus monótonos companheiros, que aumentavam em número pelas frequentes febres recorrentes da aldeia ribeirinha. Com uma casa cheia de crianças doentes, descansando em redes que há muito perderam sua brancura, como ela poderia manter todas penteadas e limpas? Como poderia ganhar dinheiro suficiente vendendo suas rendas para comprar peças de algodão e fazer roupas novas para sua família? Como poderia mandá-los para a escolinha da vila? Ela nunca tinha aprendido a ler, mas agora queria aprender. Talvez, se ela pudesse enviar seus filhos para aprender, eles poderiam ensinar-lhe algum dia, pois ela tinha apenas vinte e cinco anos, embora tivesse nove filhos ${ }^{10}$. (MILLS, 1976, p. 82-83, tradução nossa).

\footnotetext{
9 "Maria Piauí had belonged to a poor peasant family and had never learned to read. She was now over thirty, crippled with the effects of disease, but enthusiastic. Every day she came, learned quickly, memorized many portions of Scripture, her joy. Instead of the old Maria, dirty and unkempt, we now say the new Maria walking along the street with a radiant face, clean clothes and combed hair, her Bible under her arm. She was on her way to her former companions in sin. They jeered, called her a hypocrite for carrying a Bible when they knew she couldn't read. She opened her Bible and read to them a portion she had memorized, pointing with her finger to each word slowly. They were amazed."

10 "[...] my heart went out to these hidden-away womenfolk, slaving from morn till night over an iron pot on a fire made on the mud floor. This fire was kept in place by three large stones, on which the pot rested, and the curling
}

Práxis Educativa, Ponta Grossa, v. 14, n. 3, p. 915-937, set./dez. 2019 Disponível em: <http://www.revistas2.uepg.br/index.php/praxiseducativa> 
As muitas Evas de uma história: a produção de um lugar a partir da publicação de autobiografias...

Essa descrição de uma rotina doméstica vivida por uma mulher jovem e com muitos filhos dá conta da representação do estilo de vida da mulher pobre do interior maranhense: planta, colhe e pila, depois cozinha em fogão de pedra; tece rendas para vender; ou lava e passa roupas para ganhar algum dinheiro e comprar tecido para costurar as roupas das próprias crianças. Quando essas crianças adoecem, como manter a rotina para sustentá-las? Essa mulher também queria aprender. Eva Mills deixa a interrogação subtendida: o que seria diferente se essa mulher pudesse ir à escola?

$\mathrm{Na}$ maior parte das narrativas de Eva Mills sobre as mulheres, elas não são associadas à figura masculina, apesar de às vezes reclusas no ambiente doméstico, como na descrição anterior. Quando a associação ao marido aparece, é para trazer a representação sobre ser uma boa esposa e mãe, dentro dos padrões requeridos para a mulher protestante e burguesa dos séculos XIX e XX (SILVA, 1998, 2015).

É o caso do relato sobre uma visita feita à família de Joaquim Bina e Vitória, no início do Colégio Cristão, em 1932. A representação do ambiente da casa é de companheirismo e alegria, quando todos (a família e os missionários) sentaram-se ao redor de uma grande mesa para a refeição. O espaço da cozinha é o que ganha mais entonação neste traçado pelo perfil de mulher apresentado:

O centro da casa, de onde irradiava amor, alegria e paz era a cozinha, com a mãe, Vitória, no fogão. A vitória estava em seu rosto, em sua voz e em suas atitudes. Isto vinha de sua gratidão a Deus pela salvação em Cristo, para si mesma, para seu marido Joaquim e seus filhos crescidos, que estavam refletindo a Ele, seu Senhor, que fez toda a mudança em sua casa. O que me atraiu para a cozinha, como um ímã, foi a atitude de todas as crianças para com sua mãe. Como eles a amavam e estavam prontos para fazer qualquer coisa à sua mais ínfima sugestão! Ela nunca levantava a voz, mas o olhar de amor em seus olhos me fez querer me aproximar para abraçar esta querida irmã em Cristo. As crianças percebiam também, no brilho daqueles grandes olhos marrons, que haveria uma surpresa para eles mais tarde. Era uma surpresa diária, mas que nunca perdia sua diversão, pois ela sempre mantinha sua palavra. Ela era mãe dos três jovens que iriam comigo para Balsas. Antes de partirmos da casa dos Bina, eu percebi um pouco do sacrifício que ela estava fazendo e o quanto eles sentiriam a falta da mãe, mesmo que não fossem mais crianças. Ela é que trouxera conforto para cada um deles quando o filho mais velho morreu tão repentinamente. $\mathrm{E}$ agora, ela os inspirava a continuar confiando no Senhor, de quem ela era uma seguidora devota ${ }^{11}$. (MILLS, 1976, p. 96, tradução nossa).

smoke of the burning logs found its way into the eyes of the child, who held a palm-leaf fan to keep the flame alive, and then out through the blackened palm-leaf roof, as best it could find a way. From time to time the mother stirred the beans with a large wooden ladle or spatula. Sometimes in the back yard, this wife would pound the corn she had gathered and carried from their little plot of land some distance from the home. Sometimes at the river edge she squatted and beat the well-soaped clothes on a board, or, failing that, on a stone. Sometimes, in the badly lighted open room of their home, she passed the cumbersome, smoky iron, filled with glowing coals from the fire, over the clothes of some town official, and the sweat and smoke mingled on her worn, cotton dress, when she wiped her face for relief. Flies, heat, poverty and other discomforts were her monotonous companions, increased at times by the oft recurring fevers of the riverside village. With a houseful of sick children, lolling around in hammocks that had lost their whiteness, how could she keep them all combed and clean? How could she earn enough money, by her pillowlace making, to buy cotton goods and make new clothes for her family? How could she send them to the little village school? She had never learned to read but she longed to know how. Maybe, if she could send her children to learn, they might teach her someday, for she was only twenty-five, even though she had nine children."

11 "The center, from which radiated love, joy, peace, was the kitchen, the mother at the stove, Vitória. Victory was in her face, her speech, her attitude. It came from her gratitude to God for salvation in Christ, for herself, her husband Joaquim and her older children, who were showing about Him, their Lord, who had made such a change in their home. What drew me to the kitchen, like a magnet was attitude of all the children to their mother. How they loved her and were ready to do anything at her slightest suggestion! She never raised her voice, but the look of love in her

Práxis Educativa, Ponta Grossa, v. 14, n. 3, p. 915-937, set./dez. 2019 Disponível em: <http://www.revistas2.uepg.br/index.php/praxiseducativa> 
Vitória é a grande representação do papel de mãe nos livros de Eva Mills: seu lugar era a cozinha, e para lá todos eram atraídos. Seu rosto, sua voz e suas atitudes expressavam as mudanças de comportamento requeridas para a mulher convertida ao protestantismo. Exemplo de amor aos filhos, abnegação, trato divertido e respeitoso com as crianças, além do companheirismo com o marido. Uma mãe que fez ainda o sacrifício de separar-se dos filhos para que estes fossem estudar na escola dos missionários.

\title{
Eva Mills, uma missionária e professora
}

O segundo livro publicado por Eva Mills, Em lugar do espinheiro, é um compêndio de biografias, apresentado como "[...] um relato das experiências de homens de Deus, chamados a servi-lo em lugares difíceis [...], homens que expuseram as suas vidas pelo nome de Cristo, que sofreram no trabalho do evangelho" (MILLS, [1982?], apresentação). A proposta de Eva Mills foi evocar os homens mais ou menos importantes que conheceu, acompanhou ou com quem conviveu no Brasil, parafraseando Michelle Perrot ${ }^{12}$, em período de inserção do protestantismo no interior do Maranhão.

Nesse livro, Eva Mills traz poucas mulheres além de si mesma. Algumas aparecem figurando o papel de boas esposas, como Ana, a esposa brasileira do missionário canadense Perrin Smith. Mãe, corajosa, independente, administrava a casa, filhos e propriedades da família enquanto o marido passava de seis a sete meses ausente em viagens evangelísticas.

Ana, esposa do evangelista ${ }^{13}$ Patrício Cavalcante, e Vitória, esposa do evangelista Joaquim Bina, foram mães abnegadas que choraram a morte dos filhos, que seguiram seus maridos na fé e mantiveram a harmonia de suas casas. Antônia foi a parceira missionária em companhia de Chico, desbravando terras longínquas em viagens evangelísticas. Hosana, por sua vez, assumiu o casamento com Natal e o cuidado do marido, que sofria de framboésia ${ }^{14}$, como a sua vocação de vida.

Miriã é a única mulher biografada no livro Em Lugar do Espinheiro que recebeu um capítulo para si. Ela representa a trajetória de uma de suas próprias filhas (crianças cuidadas por Eva Mills):

\begin{abstract}
Miriã amava sua mãe profundamente e as duas se davam muito bem. Quando, após ter passado um ano de sua experiência de salvação, Margarida faleceu ao dar à luz, Miriã ficou tomada de dor. Como filha mais velha, ela ajudou muito, cuidando da casa e de seus cinco irmãos menores. Havia a água para ser carregada para o serviço doméstico, havia roupa para lavar, refeições para preparar [...].
\end{abstract}

\footnotetext{
eyes made me want to get near to embrace this dear sister in Christ. The children detected, also, in the twinkle of those big brown eyes, a surprise for them later on. It was a daily surprise, but it never lost its thrill, because she always kept her word. She was the mother of the three young people who were to go with me to Balsas. Before we left the Bina home I knew a little of the sacrifice she was making and how much they would miss her, even though they were no longer children. She was the one who had brought comfort to each one when the oldest boy had died so suddenly. She inspired them now to keep on trusting the Lord, of whom she was a devoted follower."

12 "'Minha vida não é nada', diz a maioria das mulheres. Para que falar dela? A não ser para evocar os homens, mais on menos importantes, que conbeceram, acompanharam ou com quem conviveram" (PERROT, 2016, p. 28, grifo nosso).

13 O termo "evangelista" era usado com referência a brasileiros, enquanto o termo "missionário" referia-se a pessoas que vieram de outros países para o Brasil, independentemente de suas funções. Na prática, o trabalho de ambos (brasileiros ou estrangeiros) se assemelhavam e as expressões serviram para categorizar e dar distinção hierárquica.

14 Também conhecida por frambesia ou bouba, é uma doença que se caracteriza pela presença e proliferação de úlceras pelo corpo. Atinge inicialmente mãos, pés, couro cabeludo e tronco, podendo chegar a alterações nos ossos, como encurtamento de dedos, em um ciclo semelhante à lepra. (Disponível em: <https://medicaldictionary.thefreedictionary.com/framboesia >. Acesso em: 6 jul. 2018).
}

Práxis Educativa, Ponta Grossa, v. 14, n. 3, p. 915-937, set./dez. 2019 Disponível em: <http://www.revistas2.uepg.br/index.php/praxiseducativa $>$ 
As muitas Evas de uma história: a produção de um lugar a partir da publicação de autobiografias...

Quando eu estava substituindo alguns missionários em férias no internato de Breves internato que existia para ensinar as crianças da área do Rio Amazonas onde não havia escola - olhei na direção do rio e vi chegar um barco com cinco crianças. Três eram filhos de Margarida. Miriã, que era um deles, se atirou em meus braços dizendo: "Nós somos seus agora. Antes de morrer mamãe disse para virmos para cá”. (MILLS, 1982, p. 47-48).

A descrição de Miriã é de uma menina que sofreu com a perda da mãe e precisou amadurecer muito rápido. Assumiu seus irmãos menores, ensinando e cuidando como uma mãe durante o crescimento deles. A figura maternal de Miriã em relação a seus irmãos diz de um cuidado espiritual constante, com as devidas reprimendas, amor e paciência, como parte de seu novo papel, de sua "missão do lar" (SEIGUER, 2015).

Eva Mills assumiu o cuidado e a educação dessas crianças quando estava no internato em Breves, no Pará, para onde elas foram enviadas. Quando voltou para o Maranhão trouxe-as consigo para a Escola Maranata, onde Miriã também estudou, depois indo trabalhar entre os indígenas como missionária. Eva Mills acompanhou o desenvolvimento de Miriã até ela tornar-se uma missionária reconhecida e respeitada entre os seus. A vida de sucesso postulada por Eva Mills à Miriã, posto ela ter se transformado em uma missionária, a integrou a essas narrativas.

Eva Mills, por sua vez, tal qual Miriã, nesse livro aparece como uma "missionária", partícipe do rol de pioneiros embaixadores. Ela atravessou as selvas montada em cavalos ou jumentos, enfrentou carrapatos, espinhos etc., assim como os demais de seu grupo. Nos relatos autobiográficos presentes no Em lugar do espinheiro, Eva Mills se representa não como acompanhante do seu marido, mas como integrante do grupo de outros missionários durante as viagens, sem mencioná-los por nome. Pelo contexto narrado e pelo cruzamento entre as narrativas, é possível identificar alguns dos nomes das pessoas que compunham os grupos aos quais ela se refere; e, em alguns deles, David Mills estava presente. Contudo, é interessante perceber que ela não o identifica, apenas se refere ao grupo como "nós": "Nós seguimos a viagem", "nós acordamos e amarramos nossas redes", "nós seguimos o guia". "Nós". Ela era uma missionária como qualquer um dos demais homens do grupo, sem nenhum tipo de distinção, diferentemente da narrativa do livro anterior.

Já em Stories from parakeet country, o terceiro livro, a Eva Mills "professora" aparece com mais força. Ela não precisava mais se preocupar em remontar a história de uma "esposa de missionário", como acontece no 8:28; nem de assegurar seu lugar no grupo como uma "missionária". Apesar de já vir se identificando como educadora, narrando suas escolas, questionando o acesso das mulheres à educação escolar, é nessa obra que sua pertença à educação é acentuada, desde a forma da narrativa - de maneira didática e diretiva, voltada ao ensino de crianças e de adolescentes - ao enredo de suas histórias, que se desenrolam no ambiente escolar. Também é aqui que fica mais evidente o poder libertador que Eva Mills atribui à educação, em especial para as mulheres.

Linda, uma das personagens de Eva Mills, foi uma menina criada pela mãe e pela avó dentro dos padrões da religião. Elas

[...] encorajavam-na a ler sua Bíblia para que ela crescesse para ser uma adolescente prestativa e bela, e fizesse sua confissão de fé em Jesus Cristo. Sua mãe acompanhou de perto e guiava seus passos de uma maneira tão amorosa que Linda apreciava o conselho de sua mãe - até que um dia... ${ }^{15}$ (MILLS, 1986, p. 30, tradução nossa).

\footnotetext{
15 "Encouraged her to read her Bible so that she grew to be a helpful, beautiful teenager, and made her confession of faith in Jesus Christ. Her mother kept a close watch and guided her steps in such a loving way that Linda appreciated her mother's advice - until one day..."
}

Práxis Educativa, Ponta Grossa, v. 14, n. 3, p. 915-937, set./dez. 2019 Disponível em: <http://www.revistas2.uepg.br/index.php/praxiseducativa > 
Linda é descrita como que indecisa entre dois mundos: a oportunidade de ir à escola na cidade mais próxima, ou o namoro com o moço por quem tinha se enamorado. Linda optou por estudar na Escola Maranata a fim de se preparar para o treinamento do Instituto Bíblico, o que deixou sua mãe e avó encantadas com a decisão. Seu pai, por outro lado, achava que seria bom se Linda pensasse seriamente em casamento e no bom partido que era o rapaz. Durante o ano letivo na escola, a saudade a fez titubear em sua decisão e mais de uma vez ela reconsiderou seu futuro.

Toda essa história é narrada em suspense, provocando expectativa em relação à decisão de Linda, como uma verdadeira batalha entre dois tipos de vida que, naquele momento, eram destoantes: o casamento e a permanência na vila e, assim, a perpetuação de um estilo de vida; ou a possibilidade de galgar outros sonhos - ser professora e missionária -, a conquista de seu espaço público e a mudança de vida.

Segundo Eva Mills, Linda “venceu a batalha”: concluiu seus estudos na Escola Maranata, foi para o Instituto Bíblico e tornou-se missionária, também ensinando outras crianças a ler e a escrever. Um ciclo precisou ser interrompido e o "destino feminino" fora questionado.

As comodidades de um apoio viril são assaz tentadoras, comparadas com os riscos de uma carreira e a severidade que implica todo verdadeiro trabalho. $O$ desejo de um destino feminino - marido, lar, filhos - e o encantamento do amor nem sempre se conciliam com a vontade de vencer. (BEAUVOIR, 1980, p. 472).

A utopia da realidade de Linda, naquele momento, era agregar o amor e a "vontade de vencer”. Diante dessa impossibilidade, Linda escolheu vencer.

A vovó Lã é outra personagem nessas histórias. Eva Mills a descreve a partir de uma rotina diária da vida doméstica. Ela era trabalhadora, limpa e contemplativa:

Eu a chamava vovó Lã porque seu cabelo era como a lã de uma ovelha, da mesma cor. Ela era magra e velha. Não sabia quando era seu aniversário nem o ano em que havia nascido. Nunca havia tido um bolo de aniversário.

Vovó Lã morava sozinha em uma barraca feita de folhas de palmeira. Do lado de fora da casa podia descansar e contemplar o pôr do sol por volta das seis horas toda noitinha [...]. Ela dormia numa confortável rede feita em casa, como todas as pessoas naquela parte do Norte do Brasil, onde o clima era sempre quente, noite e dia, o ano todo; ela nunca tinha visto neve e a geada nunca havia tocado suas árvores. [...].

Todas as manhãs ela acordava logo que o primeiro raio do amanhecer entrava em seu quarto. Sua rede era enrolada e presa firmemente na corda que a prendia à viga. Ela fazia seu foguinho no chão de terra da cozinha e uma velha lata de água era colocada habilmente sobre as três pedras que formavam o fogo. Vovó Lã colocava alguns torrões de açúcar escuro na lata de água para adoçar o café que ela mesma torrava, batia e mantinha em uma lata fechada. Pendurada no teto de palha estava um saco de algodão, um pouco menor que a lata que estava no fogo. Era nele que ela passava seu café toda manhã. No saco tinha um aro de arame costurado em volta do topo e uma alça torcida feita do mesmo pedaço de arame forte. Quando a água estava quase fervendo, vovó Lã colocava um pouco do café torrado no saco e o mergulhava na água fervente, deixando o aro de arame em volta da lata. Depois de alguns minutos, retirava o saco, comprimiao e desfrutava do seu café da manhã.

Vovó Lã era uma senhora muito ocupada. Não podia ficar sentada por muito tempo. Ela conseguia varrer o chão de sua casa e o quintal ao redor dela todas as manhãs antes do sol subir acima das bananeiras no fundo de seu quintal. Não havia lugar para cobras se esconderem na casa da vovó Lã. [...].

Práxis Educativa, Ponta Grossa, v. 14, n. 3, p. 915-937, set./dez. 2019 Disponível em: <http://www.revistas2.uepg.br/index.php/praxiseducativa> 
As muitas Evas de uma história: a produção de um lugar a partir da publicação de autobiografias...

Foi quando seus vizinhos, vendo sua casa e sua vida limpa, decidiram acompanhá-la para ver como era a reunião de que ela tanto falava ${ }^{16}$. (MILLS, 1986, p. 35-36).

Vovó Lã é rememorada por suas atitudes e exemplo no espaço doméstico. Sempre ativa, prezava por um ambiente limpo, longe das cobras, a ponto de ser influência na localidade, sendo capaz de levar muitas pessoas aos encontros religiosos.

A imagem da serpente tem um duplo sentido nesse contexto: o perigo real - o veneno da cascavel é mortal, uma ameaça constante para quem vive perto das matas - e o sentido religiosocristão, em que a serpente é associada também à morte no sentido espiritual, ao pecado e à inimizade com Deus. Na narrativa bíblica, a serpente representa a figura do mal entre os fiéis. Desse modo, a associação do ambiente limpo com as pessoas convertidas ao mesmo tempo que figura o modelo higienizado e civilizado dos convertidos, também diz sobre a identidade de um grupo que demoniza um outro e o mantém a certa distância como um mal ou perigo.

Apesar de estar no ambiente doméstico, vovó Lã não é exaltada no ambiente familiar, em sua relação com o marido, como esposa ou mãe. Eva Mills não diz que se tratava de uma senhora solteira, viúva ou divorciada. Apenas a relata só, quando recebeu sua neta Leni com sete anos de idade, que veio morar com ela depois do falecimento de sua mãe.

Conhecemos dona Lenir Lopes Bezerra, a "pequena Leni" dessa história, em seus 72 anos de idade. Segundo D. Lenir, Antônia Costa Silva era a Mãe Antônia para ela e os demais filhos e netos, e Antônia Lã, ou Dona Lã, para os demais. Quando a mãe de D. Lenir morreu, ela e mais dois irmãos foram morar na casa da Mãe Antônia, sua avó materna. À época, ela estava casada com o terceiro marido, pois tinha enviuvado dos outros.

16 "I called her Grandma Wool because her hair was just like the wool on a lamb's back, even the color. She was thin and old. She did not know when her birthday was, nor the year she was born. She had never had a birthday cake.

Grandma Wool lived alone in a tiny shack made of palm leaves. On the outside of her home where she could rest and watch the sunset about six o'clock each evening [...]. She slept in a comfortable homespun hammock, as did all the people of that part of North Brazil, where the weather was always warm, day and night, all the year round; she had never seen snow and the frost had never touched her trees. [...].

Every morning she was up when the first streak of dawn made a little shadow in her room. Her hammock was soon rolled up and fastened securely under the rope which held it to the beam. She made her little fire on the dirt floor of the kitchen and an old can of water was set deftly on the three rocks that made her fireplace. Into the can of water she dropped a few lumps of dark brown sugar. That was to sweeten her coffee, which she roasted and pounded herself and kept in a tightly closed can. Hanging on her palm leaf was a cotton bag, a little shorter than the can she had put on the fire. In it she strained her coffee every morning. The bag had a wire hoop sewn round the top and a twisted handle made of the same piece of heavy wire. When the water on the fire was about to boil, Grandma Wool put some of her home roasted coffee in the bag and let it sink to the bottom of the boiling water, leaving the wire hoop around the top of the can. After a few minutes of brewing, she took the bag out, squeezed it and enjoyed her early morning coffee.

But Grandma Wool was a busy lady. She could not sit around very long. she managed to sweep the floor of her home and the yard all around it every morning before the sun rose above the banana plants at the bottom of her yard. there was nowhere for snakes to hide in Grandma Wool's home. [...].

That was where her neighbors, seeing her clean home and clean life, had decided to accompany her to see what the meeting she had talked so much about were like."

Práxis Educativa, Ponta Grossa, v. 14, n. 3, p. 915-937, set./dez. 2019 Disponível em: <http://www.revistas2.uepg.br/index.php/praxiseducativa> 
Nas memórias de D. Lenir, Mãe Antônia conheceu a Cristo ainda nova, no primeiro casamento, levada pela irmã para as Convenções em Barra do Corda ${ }^{17} \mathrm{e}$ "[...] assim que se converteu aprendeu a ler na Bíblia [...] ela disse que aprendeu a ler na Bíblia, e lia e pregava..." (BEZERRA, [entrevista], jan. 2017) ${ }^{18}$.

Eles moravam no povoado de Bom Princípio, em Esperantinópolis (MA). Lá,

[...] o salão de cultos ficava na casa da minha avó, ela era quem dirigia os cultos. [...] Mãe Antônia evangelizava muito, ia nas casas das pessoas no domingo à tarde [...]; nas férias do Instituto, enchia de alunos lá em casa [...] foi lá que conheci a Geni, que me levou pra escola. (BEZERRA, [entrevista], jan. 2017).

D. Lenir conta que, recentemente, na comemoração de aniversário de uma igreja no município de Tuntum (MA), D. Antônia Lã fora rememorada como uma precursora daquela congregação. "Eu nem sabia disso?', lembra com entusiasmo. D. Lenir ressalta que, nesta cidade, ela também era conhecida como "mão santa", pois sabia preparar muitos remédios de "cascas de pau", óleo de buriti e etc., e era sempre chamada quando alguém estava doente - "ela ajudava muito as pessoas" (BEZERRA, [entrevista] jan. 2017).

O relato de experiências de mulheres como Antônia Lã denuncia o anonimato sobre a participação feminina em sociedades rurais e suas posições de liderança ocupadas na formação de um protestantismo sertanejo, distante dos padrões protestantes europeus ou norte-americanos. Por certo uma mulher como Antônia Lã não foi única e é representativa de uma geração de mulheres que procurou se alfabetizar para ler a Bíblia, visitava para evangelizar construindo outras formas de sociabilidade, pregava em cultos e não se ocultou por trás de figuras masculinas em seu grupo. Dona Antônia Lã "vivia da roça" de suas próprias quintas, era independente e casou três vezes depois que se converteu. Era procurada pelos enfermos da região para seus remédios, cuidados e orações. Manteve uma congregação em sua casa, ponto de apoio para os estagiários do Instituto Bíblico do Maranhão, além de ter iniciado outras congregações em outros lugares.

Contudo, o impacto pelas narrativas destoantes entre Eva Mills e D. Lenir sobre a vovó Lã nos instigaram a novos questionamentos. Vovó Lã e Mãe Antônia são a mesma pessoa, mas sob memórias e representações diferentes. Se nosso interesse fosse confrontar dados sobre uma possível veracidade dos fatos, talvez o caminho fosse procurar pela verdadeira história da vovó Lã. No entanto, a versão de D. Lenir despertou-nos para o conjunto das representações sobre as mulheres trazidas nos livros de Eva Mills.

Todas as personagens de suas histórias são reais a partir do olhar da autora. São muitas mulheres narradas, idosas, jovens, crianças, e há algo em comum em todas elas. Os recortes dessas mulheres chamam atenção para a representação e a construção identitária da própria autora. A entrevista com D. Lenir suscitou muitos questionamentos e foi inspiradora para a construção dessa etapa da pesquisa.

\footnotetext{
${ }^{17}$ Iniciada na década de 1930, havia uma prática entre o grupo de prosélitos daquela região no interior do Maranhão em "[...] organizar reuniões anuais em Barra do Corda, chamadas de Convenções, durante o período de lua cheia no mês de junho ou julho. Para lá os crentes evangelizados por Perrin Smith convergiam de várias localidades para uma semana de estudos bíblicos, testemunhos, integração comunitária, além de se constituir o único espaço, segundo Mills $(1976,1982$, 1986), para aprendizagem de passagens bíblicas por meio da memorização, visto se tratar de um público analfabeto e leigo" (VERAS, 2017, p. 117).

${ }^{18}$ Entrevista concedida à pesquisadora em 21 de janeiro de 2017.
}

Práxis Educativa, Ponta Grossa, v. 14, n. 3, p. 915-937, set./dez. 2019 Disponível em: <http://www.revistas2.uepg.br/index.php/praxiseducativa> 
As muitas Evas de uma história: a produção de um lugar a partir da publicação de autobiografias...

Voltando à narrativa do livro, após a chegada da pequena Leni à casa da vovó Lã, a descrição novamente segue sobre a rotina da casa, das coisas que a avó procurou ensinar à neta. Além de consolar a pequena em sua perda materna, buscando conforto na relação com o Sagrado, a vovó Lã também se preocupou em ensinar à menina as tarefas diárias de uma dona de casa:

\begin{abstract}
Ela achou que era um grande desafio e Leni era boa companhia, esperta e animada, ansiosa para aprender e a vovó Lã tinha muitas coisas para ensinar a sua nova companheira. Ela mostrou a Leni como cozinhar arroz e feijão, como torrar café, conservar a casa limpa e o quintal em ordem, livre das cobras venenosas. Havia potes d'água para encher no riacho e Leni devia aprender como equilibrar uma cabaça de água na cabeça enquanto caminhava no retorno até a casa. Ela deve ter mostrado como abaixar a cabaça cheia de água sem derramar nada e, cuidadosamente, derramar o seu conteúdo nos potes de água arrumados em um banco especial. Havia galinhas para alimentar, a cabra para ordenhar, plantas para molhar, roupas para lavar no riacho e muitas outras coisas para fazer, como fazer sabão ou fazer rendas para almofadas, quando as outras tarefas estavam prontas $^{19}$. (MILLS, 1986, p. 37-38, tradução nossa).
\end{abstract}

Entretanto, a exemplo da história de Linda, Leni também teve a chance de mudar o ciclo de sua vida e não perpetuar a rotina de sua avó ou mãe, por meio da oportunidade de estudar na escola cristã aberta pelos missionários, a mesma Escola Maranata onde Linda estudou. Percebamos qual é o papel da escola protestante na vida dessas crianças que, para além de cumprir um papel religioso, dando acesso à leitura da Bíblia, ou mesmo cumprir uma função na mudança de comportamento social, também se configurava como uma oportunidade de mudança e quebra do ciclo de uma vida, em especial para as meninas. $O$ fato de ir à escola era a conquista de um outro mundo possível: elas poderiam ser professoras ou missionárias. Ou as duas coisas. Elas não precisavam, necessariamente, casar ou ter uma vida reclusa. Poderiam, sim, legitimar-se em um espaço público considerado digno e aceitável para as mulheres da época.

A história que Eva Mills narra sobre a menina Leni é estendida por mais um capítulo para além da história da vovó Lã, em que a autora apresenta um pouco da rotina na escola para as meninas:

\begin{abstract}
Dez garotinhas, todas entre oito e dez anos de idade, moravam na Casa Felicidade no terreno da Escola Maranata, no Norte do Brasil. Elas plantavam um pequeno jardim de flores, brincavam com suas bonecas feitas em casa, faziam roupinhas de boneca e vestiam-se como mães cuidando de seus bebês; e ninguém gostava mais dessa brincadeira do que Leni. Geni era a mãe da casa e todas as garotinhas a amavam e faziam o que ela mandava. Elas iam para a escola todas as manhãs e brincavam à tarde. Aos sábados, brincavam o dia todo depois que suas pequenas tarefas eram realizadas. Frequentemente brincavam de igreja. Uma das garotas sentava no órgão de faz de conta e muitos hinos eram cantados ao som de sua música de faz de conta. O pregador era escolhido por turnos, mas na maioria das vezes era Leni quem pregava. Ela frequentemente repetia o que ouvia o pregador dizer no culto de domingo no prédio escolar $^{20}$. (MILLS, 1986, p. 40-41, tradução nossa).
\end{abstract}

\footnotetext{
19 "She found it to be quite a challenge and Leni was good company, bright and cheerful, eager to learn and Grandma Wool had many things to teach her new companion. She must show Leni How to cook rice and beans, how to roast coffee, to keep the little home clean and the yard tidy, free from the poisonous snakes. There were water pots to fill from the stream and Leni must learn how to balance a gourd of water on her head as she walked up the path to the home. She must be shown how to lower the gourd full of water and not to spill any as she carefully poured its contents into the water pots arranged on their special bench. There were chickens to feed, the goat to milk, plants to water, clothes to wash in the stream, and so many other things to attend to, like soap making and pillow lace, when the other chores were done."

20 "Ten little girls, all between eight and ten years old, lived in the House of Happiness on the grounds of the Maranatha School in North Brazil. They planted a little garden of flowers, played with their home-made dolls, made
}

Práxis Educativa, Ponta Grossa, v. 14, n. 3, p. 915-937, set./dez. 2019 Disponível em: <http://www.revistas2.uepg.br/index.php/praxiseducativa $>$ 
Essa dubiedade e até incongruência entre o que parece próprio às mulheres, a rotina da vida doméstica e as possibilidades da vida pública, proporcionada pelos ambientes religioso e escolar, é uma constante nas representações de mulheres trazidas pela autora. As brincadeiras das meninas na Escola Maranata revelam o espaço cativo da maternidade, do cuidado do lar, mas também suas expectativas em relação à vida pública. A música e a oratória na igreja significam formas de ocupar o espaço público e ter direito a voz, destaque e respeito no e pelo grupo. Era isso que as crianças almejavam e talvez já fosse essa a experiência vivenciada em suas igrejas nos vilarejos, sob a liderança de mulheres como a D. Antônia Lã, mas que não era uma prática oficial. Ao construírem-se como professoras ou preletoras em ambiente lúdico, dirigindo e cantando à frente de cultos de faz de conta, essas meninas estavam assumindo para si representações que iam muito além do ambiente restrito ao espaço doméstico, de esposas ou mães, sem, contudo, negálo. Pelo menos esse era o estilo de vida desejado pelas meninas-mulheres, sob o discurso de Eva Mills.

Essas narrativas de mulheres, crianças, adolescentes, idosas podem ser concluídas com o texto de "eu matei uma cascavel" (MILLS, 1986, p. 49), em que Eva Mills traz a si como protagonista nas páginas finais de Stories from Parakeet Country. O ambiente era do Sítio Maranata, onde funcionava o internato de mesmo nome:

As cascavéis pensam? Será que aquela estava esperando que as crianças viessem do rio? Eu a vi pelas rótulas da minha janela. No início ela estava deslizando suavemente; eu podia ver todos os cinco pés [mais ou menos um metro e meio] de seu comprimento através da grama fina perto do caminho. O que eu deveria fazer? A casa que chamávamos de Saudade era o lar de cerca de dez meninos de sete a nove anos de idade. Era a hora do banho. Eu podia ouvir suas vozes enquanto eles riam na água cintilante do rio Corda, logo na descida do morro. O banho estava quase chegando ao fim e eles logo subiriam o morro tomando o caminho de casa.

A cascavel continuava lá, muito perto do caminho onde as crianças pisariam. Eu estava sozinha. Não havia ninguém a quem eu pudesse pedir ajuda. Bendita, a casa mais próxima, onde viviam as meninas mais velhas, ficava ainda mais acima da colina e a uma certa distância da Saudade. Não havia tempo para correr atrás de alguém que tivesse mais experiência em lidar com cobras. Só havia uma coisa a fazer. Mas, onde encontrar uma arma apropriada e ainda manter meu inimigo à vista? Essa machadinha? Curta demais! Eu ficaria muito perto para estar segura! Eu tinha ouvido que as cascavéis não se enrolam antes de atacar. Elas nunca atacam enquanto ainda estão deslizando, já me haviam dito. Eu rastejei lentamente segurando a machadinha em posição. Já podia ouvir as crianças voltando do rio. Não havia tempo a perder. Cravei a machadinha!!!! ${ }^{21}$. (MILLS, 1986, p. 49-50, tradução nossa).

little doll clothes, dressed up as mothers caring for their babies, and no one enjoyed this better than Leni. Geni was their house mother and all the little girls loved her and did what she told them. They went to school each morning and played in the afternoons. On Saturdays the children played all day after their little duties were done. They often played at church. One of the girls sat by a make-believe organ and to her make-believe music many hymns were sung. The preacher was chosen by turns, but more often than not Leni was the one who preached. She often repeated what she had heard the preacher say at the Sunday service in the school house."

21 "Do rattlesnakes think? Was this one waiting for the children to come from the river? I saw it through the open shutters of my window. It was sliding along slowly at first; I could see all five feet of its length through the thin grass near the path. What should I do? The house we called "Saudade" was the home of about ten boys from seven to nine years of age. It was bathing time. I could hear their voices as they laughed in the sparkling water of the River Corda, just down the hill. The splashing would soon be over now because bathing time was almost gone and soon they would be climbing the hilly path homewards.

The rattler was still there, too close to the path where children's feet would tread. I was alone. There was no one I could send for help. "Bendita" the nearest children's home, where the older girls lived, was still further up the hill and was hardly within calling distance from Saudades. There would not be time to run for some-one more experienced in tackling rattlers. There was only one thing to do. But where could I find a suitable weapon and still

Práxis Educativa, Ponta Grossa, v. 14, n. 3, p. 915-937, set./dez. 2019 Disponível em: <http://www.revistas2.uepg.br/index.php/praxiseducativa> 
As muitas Evas de uma história: a produção de um lugar a partir da publicação de autobiografias...

Crianças estavam sendo ameaçadas pelas armadilhas da natureza: havia uma cascavel em seu caminho. Perigo mortal. Eva Mills diz que estava só, não havia ninguém mais experiente que pudesse salvar as crianças, então resolve interferir, assumindo ela mesma o risco sobre si e enfrentando a víbora. Calculou o problema, planejou, atacou: "cravou a machadinha!".

Essa cena lembra uma outra imagem, a primeira narrada no livro 8:28, quando Eva Mills se vê também em conflito, igualmente só em uma colina e o desafio em suas mãos de abrir ou não uma escola para "filhos de crentes pobres e analfabetos":

Eu estava em uma colina com vista para uma pequena cidade no Norte do Brasil. O desafio de iniciar um lar e escola para filhos de crentes pobres e analfabetos parecia demais para mim. Como eu poderia dizer "sim" para uma tarefa tão grande? Como ouso tentar isso? Quanto mais tempo eu passava ali, mais convicta ficava do real problema $[\ldots]$.

A cena ao meu redor era maçante. Não havia chuva desde maio e agora era outubro. O solo seco, as plantas murchas, ressequidas pela longa estação seca desta parte tropical do Brasil me lembrou de minha condição espiritual22. (MILLS, 1976, p. 11, tradução nossa).

Em ambas as situações, Eva Mills narra-se sozinha diante de um problema que precisa ser enfrentado, de algo que a inquieta e que exige atitude imediata, quase a contragosto. Em uma, uma serpente ameaçava liquidar a alegria das crianças - uma única picada seria fatal. Na outra, a realidade nefasta da pobreza e do analfabetismo e a necessidade de escolas para aquele grupo de crentes brasileiros. Adversidades que mobilizaram sua ação, questionando suas próprias representações sociais sobre o espaço da mulher no campo religioso e na sociedade. Para a abertura de uma escola, seria o momento de fazer uso de sua formação de maneira mais incisiva, assumindo-se como professora e diretora de uma escola - uma posição pública que não dependia da figura do marido ao seu lado. Diante da cobra, mais uma vez a hora de pôr em prática os conhecimentos adquiridos e assumir aquela que deveria ser uma ação de pessoa mais experiente, não dela, mas que corajosamente se dispõe a enfrentar.

Até o ano em que Eva Mills decide iniciar uma escola, ela se descreve no Brasil como esposa, mãe, ajudadora do marido, à sua sombra - é isso que marca o 8:28. Nas cartas e nos depoimentos, e mesmo nas narrativas dos livros, é possível perceber uma mulher que sempre evitou a preleção dos cultos públicos por apoiar tal cultura. Esse espaço era para os homens. Ainda assim, Eva Mills nunca esteve reclusa no âmbito privado e seu trabalho frente às mulheres já era, em si, uma conquista ${ }^{23}$. Seu espaço sempre foi o público, nas ruas, conversando com as

keep my enemy in view? That hatchet? Too short! I'd get too close to be safe! I had heard that rattlesnakes don't curl up before they strike. They never strike while they are still sliding along, I had been told. I crept slowly behind it holding the hatchet in position. Now I could hear the children on their way up the path from the river. There was no time to lose. Chop!!!”

22 "I stood on a hillside overlooking a little town in North Brazil. The challenge to start a home and school for children of poor, illiterate believers seemed too much for me. How could I say 'yes' to such an undertaking? How dare I attempt it? The longer I stood there the more convinced I was of the real problem [...].

The scene around me was dull. There had been no rain since May and it was now October. The dry ground, the withered plants, parched by the long dry season of this tropical part of Brazil reminded me of my spiritual condition."

${ }^{23}$ Considerando um momento histórico em que era negado às mulheres o acesso ao espaço público e as ruas não serem tidas como um espaço digno para elas, o trabalho missionário frente a outras mulheres poderia ser considerado uma conquista. Michele Perrot pontua que, “[...] entre as duas guerras, período que marca uma expansão real do espaço feminino, muitas jovens foram seduzidas pela nova disciplina da etnografia, logo, acessível às mulheres [...]. Por serem mulheres, podiam falar com as mulheres nativas: assim como Denise Griaule na África, Gemarmaine Tillion no Magreb” (PERROT, 2016, p. 140).

Práxis Educativa, Ponta Grossa, v. 14, n. 3, p. 915-937, set./dez. 2019 Disponível em: <http://www.revistas2.uepg.br/index.php/praxiseducativa> 
mulheres, observando, registrando, planejando, agindo, ainda que, aparentemente, evitasse o púlpito.

Contudo, é quando ela se assume professora que essa relevância pública ganha proeminência, independência e autonomia, destacando-se do trabalho do marido que se dedicava a atendimentos médicos e a viagens ribeirinhas. Com a escola, Eva Mills tornou-se "a professora", sua identidade mudou e com ela sua posição no campo e nas relações de poder vivenciadas pelo grupo também.

Nas duas situações identificadas anteriormente, parece ter sido posto à prova o papel social assumido até então como mulher; tanto a indecisão da escola quanto o caso da cascavel exigiram dela uma (re)ação ou uma nova ação, diante de uma nova realidade. Nas duas condições, o ideário religioso sob um modelo salvacionista, de heroína, é acionado, e ela assume um espaço de ação negado.

Todavia, não houve, necessariamente, mudanças de perspectivas a partir de novas ações e enfrentamentos, em termos de ruptura ou descontinuidade, pelo menos não de um novo que nasceu sem precedentes, mas negociações a partir de modelos já vivenciados anteriormente. Para a cascavel, não seria a primeira vez que Eva Mills enfrentaria seus próprios medos. Para a escola, também não.

Essas representações de si remetem às tensões culturais dos espaços do feminino nas cidades por onde Eva Mills circulou e como ela precisou negociar a partir de seus anseios religiosos. Por exemplo, o que era ser mulher em Manchester, durante seus cursos para a docência, cidade que foi palco do movimento pioneiro das sufragistas no início do século XX, mesmo período de formação de Eva Mills naquela cidade? Ou, como era ser mulher no interior sertanejo do Brasil entre aquelas que ela descreve como líderes, trabalhadoras, sempre independentes da figura masculina, apesar de confinadas no ambiente doméstico por causa da inacessibilidade à educação? Ou mesmo nos Estados Unidos, onde suas cartas relatam o encantamento com as facilidades e as praticidades proporcionadas às mulheres que saem para $\mathrm{O}$ trabalho, lugar onde ela cria vínculos e acaba se aposentando, e para quem ela escreve esses livros.

\section{As muitas $E_{V} a s$ de uma vida}

Eva Mills foi uma mulher que efetivamente circulou por várias cidades, países e culturas. A maior parte dessas viagens, ela as fez sozinha ou acompanhada por sua filha Anna Davina ${ }^{24}$. A (re)leitura de si e do outro deu-se a partir dessas múltiplas relações, dessas negociações identitárias entre culturas, em que acabam sendo reveladas as incoerências da vida gestadas por diferentes Evas, de acordo com os campos e os momentos que ela se circunscreve.

\footnotetext{
${ }^{24}$ Anna Davina é filha do casamento com David Mills. À época da separação do casal, ela estava com 8 anos de idade, ficando com a mãe no Norte e Nordeste brasileiro. Aos 13 anos passou a morar nos Estados Unidos, em colégio interno, e, depois de formada e casada, veio com o marido, George Doepp, para o Maranhão trabalhar com a mãe na Escola Maranata em Barra do Corda.
} 
As muitas Evas de uma história: a produção de um lugar a partir da publicação de autobiografias...

Há a Eva da infância, de descendência nobre ${ }^{25}$, criada entre a cidade industrial de Manchester e as férias nos campos ingleses da região de High Legh, no Norte da Inglaterra. Há a Eva da juventude, que enfrenta os pais, alimentando o desejo de (v)ir a "[...] terras selvagens e desconhecidas do Norte do Brasil” (MILLS, 1976, p. 25). Há a Eva que casa em terra estrangeira, longe da família, com o também inglês e cúmplice nos sonhos missionários, David Mills. Há a senhora Eva Mills, esposa de David Mills, a Eva Mills missionária; e há a D. Iva professora e diretora que vive em uma região "primitiva" do Brasil. Há uma Eva contadora de histórias para crianças e adultos, no Brasil e nos Estados Unidos. Há a Eva aposentada, enferma e escritora de livros. Há uma Eva autora.

Eva Mills escreve de si em sua velhice, se (re)construindo no texto em um momento de revisão da vida, de olhar para trás, mas em uma constante ressonância entre três tempos: 1. O tempo presente - quem era no momento da escrita dos livros, a síntese de tudo quanto já havia vivido, assim como as relações com as problemáticas e as prioridades daquele período e contexto social; 2. O tempo passado - o que ela viveu, o que conseguiu guardar na memória, nas anotações, nas cartas, nos impressos e nos diários, capazes de rememorar não só os fatos mas os sentimentos envolvidos; e 3. O tempo futuro - a expectativa sobre qual história e qual Eva Mills ficaria eternizada nos livros, a preocupação com a recepção de suas obras, sobre como os outros iriam receber os relatos ali registrados. Essa dialética entre tempos também é um espaço entre culturas. As culturas de agora, ainda que em uma mesma localidade, não traduzem as culturas de, por exemplo, há 50 anos, menor tempo entre os fatos vividos e a publicação dos livros.

A (re)leitura de si e do outro dá-se a partir dessas múltiplas relações, dessas negociações identitárias, dos espaços de sobrevivência e disputas no campo das relações interpessoais - o modelo do grupo e aquilo que o sujeito representa dentro do grupo -, tanto quanto da relação intrapessoal - as disputas entre a aspiração e o real. Mesmo depois de o marido ter abandonado os sonhos missionários que eram para ser vividos juntos, segundo suas expectativas e do grupo, Eva Mills continuou seu trabalho como missionária e professora, em companhia de uma filha, uma configuração fora dos padrões religiosos da época.

Independente da figura masculina, ela assegurou um espaço legítimo e de respeito dentro do campo missionário protestante, ensinando e dirigindo escolas, coordenando outros missionários, professores e professoras, ensinando alunos e alunas (suas escolas sempre foram mistas), até o momento que, em 1960, sua saúde não mais permitiu voltar ao Brasil. Não obstante, construiu uma trajetória que pôde ser retomada, dentro do campo protestante, como modelo a ser seguido por outros, o que justifica sua memorialística. Uma história de autoria da própria vida, materializada na autoria dos livros.

Nessa trajetória, é possível identificar um contraste identitário entre a "esposa" e a "professora", categorias que não se anulam, mas são capazes de definir identidades e posições sociais contrastantes. Data de 1933 a abertura da primeira escola de Eva Mills, o Colégio Cristão,

\footnotetext{
${ }^{25} \mathrm{Na}$ memória de pessoas mais íntimas à Eva Mills no Brasil, ela foi/é representada como de família e tradição (costumes) nobres da Inglaterra, sob histórias que ela mesma contava. No arquivo do pastor Abdoral Fernandes da Silva (1921-2015), foram encontrados rascunhos da narrativa construída sobre Eva Mills para o livro Nossas Raízes (1994), em que ele a identifica como uma mulher de descendência nobre que abandonara sua cultura pelo evangelho - parte da narrativa que não foi incluída no livro. Nessa pesquisa, não encontramos fontes que comprovem qualquer relação direta com alguma descendência ou tradição da nobreza inglesa, apenas indícios a partir da região onde se encontrava a fazenda de seus avós, nos campos ingleses da região de High Legh. Mas apenas indícios. Contudo, entre os brasileiros, há essa representação que foi reforçada por seus modos de agir civilizados: "andava sempre penteada e arrumada", "nunca estava com cabelos soltos", "modo de vestir impecável", sua "forma de andar", sua "educação" (forma de tratar e agir com as outras pessoas), sua "disciplina e pontualidade" são alguns exemplos de expressões usadas pelos entrevistados durante a pesquisa.
}

Práxis Educativa, Ponta Grossa, v. 14, n. 3, p. 915-937, set./dez. 2019 Disponível em: <http://www.revistas2.uepg.br/index.php/praxiseducativa> 
na cidade de Balsas, atendendo a crianças e adolescentes em regime de internato e externato. A escola funcionava nas dependências de sua própria casa, onde também moravam os alunos internos. David Mills, por sua vez, um cirurgião veterinário de formação, mas que atendia como médico no Brasil, manteve seu trabalho em regiões ribeirinhas distante da cidade onde ficava o Colégio Cristão, fazendo viagens constantes. Ao identificar-se e assumir-se como professora, Eva Mills altera sua área de atuação e circulação destinada à esposa, bem como suas representações sociais, muito antes do desenlace matrimonial, que acontece em 1939. Não foi este, portanto, o divisor de águas entre essas representações, como se houvesse um antes e um depois do ocorrido: esposa versus professora ou espaço privado versus espaço público. Contudo, essa é uma relação que representa um ponto nevrálgico nessa biografia.

Em janeiro de 2017, tivemos a oportunidade de ouvir o Sr. Jesuíno Ferreira Leite, ou apenas Seu Duca, como prefere ser chamado em seus 80 anos. Ele foi aluno no último empreendimento de Eva Mills no Brasil, a Escola Maranata, na cidade de Barra do Corda, no Maranhão. Durante a rememoração de seu tempo na escola, em primeiro lugar, como aluno, depois como funcionário, trabalhando na oficina da escola, Seu Duca relembra a professora "Dna Iva". Em sua narrativa, ele faz uma rápida menção ao "problema" que Eva Mills teve com o marido. Sabendo que Seu Duca nunca lera o 8:28 (o qual traz a descrição da separação), perguntamos o que ele conhecia sobre essa história e como soube. Eis sua resposta:

\begin{abstract}
Ela contava a história de que ela veio por Balsas, ou outro lugar por aí pelo sertão e, como missionária, e o marido dela, o Dr. Davi, era médico. Então ele saía pra um lugar, ela saía pra outro muitas vezes. Ai isso ela aconselhava muito a gente: não se separem! Porque a vida dela foi atrapalhada, começou por isso. Porque ela não tinha tempo pra ele, nem ele tinha tempo pra ela. Ficavam separados. Ele lá no serviço dele e ela no outro serviço: escola, crianças, e ele como médico... De lá eles vieram pra Colinas, aí em Colinas ele teve um caso com uma senhora lá e se separaram. Quando aconteceu, que foi descoberto tudo, ele veio, conversaram, os dois, dai ele chorou e tudo, dai, muito envergonhado, porque naquele tempo era muito escândalo, né? Horroroso, assim. Aí ela se despediu dele e ele disse que ia embora, pra ela continuar o serviço dela, e ele ia embora. Foi embora parece que para o Rio, se mandou! Ela disse que ficou olhando na porta até a hora onde ele sumiu [...], foi a última vez que ela viu. Mas ela disse que orava por ele todo dia, não tinha nada de raiva dele, só tinha esse sentimento que ela errou em não ficar com ele, certo. Ela era culpada. (LEITE, [entrevista], jan. 2017) ${ }^{26}$.
\end{abstract}

Seu Duca não soube responder se outros alunos na escola conheciam essa história ou se a professora conversava e aconselhava outras pessoas tal qual fazia com ele. Segundo sua narrativa, Eva Mills culpabilizou-se pelo desenlace, atribuindo-o ao fato dos dois trabalharem separados e ele ter, por fim, tido um "caso com uma senhora lá". As descrições do choro e constrangimento de David, e de sua partida, assemelham-se às encontradas na narrativa do 8:28. O sentimento de que ela "não tinha nada de raiva dele", nas palavras de Seu Duca, e que orava por ele todos os dias, foi encontrado também em outras fontes, como em entrevistas com outras pessoas que conviveram com Eva Mills e algumas cartas da própria missionária. Talvez essa construção narrativa se deva à apropriação de um discurso de que tenha sido realmente um erro dela, mas qual? Seu trabalho, sua independência e autonomia? Por "não ficar com ele, certo" ou pela separação que, ao que tudo indica, foi iniciativa da professora - mas que narrativas como a do Seu Duca minimizam isso, atribuindo um certo consentimento (quase um favor) de David Mills em ir embora e deixá-la continuar seu trabalho?

Os conselhos dispensados ao Seu Duca por D. Iva, segundo ele, eram que o casal deveria permanecer unido, certamente a mulher devendo estar mais próxima ao marido. Poderíamos tensionar a narrativa de Seu Duca e atribuir a ele a versão de uma história que culpabiliza Eva pelo pecado de Adão. Não duvidamos que assim seja, um olhar machista e moralizador sobre outrora. Entretanto, não seria só o dele.

${ }^{26}$ Entrevista concedida à pesquisadora em de 7 janeiro de 2017.

Práxis Educativa, Ponta Grossa, v. 14, n. 3, p. 915-937, set./dez. 2019 Disponível em: <http://www.revistas2.uepg.br/index.php/praxiseducativa> 
As muitas Evas de uma história: a produção de um lugar a partir da publicação de autobiografias...

Em uma das histórias de Stories from parakeet country, sobre uma família gregária de pássaros, Eva Mills narra o seguinte:

Garotos e garotas muitas vezes se afastam muito de casa, envolvem-se com coisas erradas e se metem em problemas. Nós periquitos estamos sempre juntos, em bando. Fazemos nossos planos juntos e nos mantemos juntos no voo. Nós simplesmente não fazemos nada sem o bando. Dormimos na mesma árvore e temos consciência de que se ficarmos longe do bando arranjaremos problemas. [...]. Em nossa comunidade cada periquito tem seu companheiro, cuja companhia dura para a vida toda. Nós sempre protegemos um ao outro, viajamos lado a lado e dormimos no mesmo galho toda noite. [...]. Então, meninos e meninas, aprendam com a feliz e gregária família dos periquitos de Barra do Corda do Norte do Brasil ${ }^{27}$. (MILLS, 1986, p. 9-10, tradução nossa).

Nossa primeira leitura sobre essa passagem avaliou os aspectos de uma educação religiosa moralizadora direcionada a crianças e adolescentes no respectivo livro. Contudo, olhar para esse extrato, sob a óptica das relações de gênero experienciadas pela autora, possibilita identificar as qualidades normativas exigidas de si, sob as representações sociais e religiosas de seu grupo de pertença. Em uma "feliz e gregária família", suas obrigações de esposa deveriam ser a de estar "sempre junto", "viajar lado a lado", dormir "no mesmo galho toda noite" e ser "companhia que dura a vida toda" - muito próximo aos conselhos recebidos por Seu Duca: “- Não se separem!”.

Partir de um ideal não alcançado, sentindo-se e assumindo-se "culpada", como indicaram as memórias de Seu Duca, por não ter atingido a expectativa pretendida, é o que justifica a Eva Mills "esposa de missionário" representada em sua autobiografia. O momento que ela não mais se figurou nessa posição foi decisivo para o abreviamento de uma narrativa que expôs as intimidades de uma desilusão e, provavelmente, de um recato social. Dessa feita, compreendemos que a separação tenha sido um ponto crítico na vida da autora, um luto vivido até seus últimos dias.

Seja por razões sociais ou subjetivas - que também são frutos das relações culturais -, consideramos na biografia de Eva Mills uma mulher que nutriu expectativas e sentimentos e, por isso, chorou as circunstâncias adversas de sua trajetória. Sua narrativa não revela apenas os seus sucessos. Ela também indica seus fracassos, suas frustrações, sua capacidade de reinvenção como contingências de uma vida privada que são refletidas e, muitas vezes, determinantes na vida pública. A vida pública de um sujeito e a vida privada não são dissociáveis e só podem ser entendidas em relação.

A forma como ela assina seu nome, por exemplo, - a maior expressão da identidade de um sujeito -, traduz a dor de alguém que talvez não tenha aceitado sua própria trajetória, ou tenha tido resistência em aceitar sua nova condição. No Brasil, ela era a D. Iva, mas sempre assinou "Mrs. Eva Mills" ${ }^{28}$, mantendo o "Mills", sobrenome da família de David"29, como seu

\footnotetext{
27 "Boys and girls wander sometimes too far from home, get entangled in wrong things and get into trouble. We parakeets keep together in a flock. We make all our plans together and keep together in flight. We just do nothing without the flock. We sleep in the same tree and know that if we stay away from the flock we would get into trouble, too. [...] In our tree community each parakeet has his mate, one mate for keeps as long as we live. We always protect her, travel with her at our side, and sleep on the same branch every night. [...] So, boys and girls, take a warning from the happy, gregarious family of parakeets from Barra do Corda of North Brazil."

28 "Mrs." é um termo usado para senhoras casadas, no inglês.

${ }^{29}$ A mudança do nome da mulher casada são resquícios de uma cultura ocidental europeia não só atribuída a um código civil, mas representativo do lugar da mulher dentro de uma sociedade patriarcalista. "Dependente juridicamente, ela perde seu sobrenome. Está submetida a regras de direito que têm por objetivo civil eminentemente proteger a família: costumes do Antigo Regime; Código civil eminentemente patriarcal, dado por Napoleão à França e mesmo à Europa, que, de algum modo, o adota e que praticamente deixa as mulheres sem nenhum direito" (PERROT, 2016, p. 47).
}

Práxis Educativa, Ponta Grossa, v. 14, n. 3, p. 915-937, set./dez. 2019 Disponível em: <http://www.revistas2.uepg.br/index.php/praxiseducativa> 
próprio nome, sendo essa a assinatura em seus livros - e, portanto, o nome pelo qual nós a identificamos, o nome que ela assumiu como seu, o seu nome de casada.

Quanto à profissão docente, no Brasil, da primeira metade do século XX, a exemplo do que já vinha ocorrendo na Europa e nos Estados Unidos, a escola estava sendo vista como um espaço público digno da mulher e a docência das primeiras letras uma profissão feminina - falase em feminização do magistério - cada vez mais associada à figura materna ${ }^{30}$. Uma associação conveniente quando se pensa nas escolas de Eva Mills como "lar e escola", quando as crianças/os adolescentes vinham de outras cidades e moravam com ela. Ela era a professora, a diretora, a mãe e a missionária. Ser professora e missionária lhe conferiu uma autoridade pública e um espaço de legitimidade possível, a ponto de ela requerer essas expectativas de vida para suas personagens. Sua própria vida foi padrão e lente para representar outras mulheres.

\section{Considerações finais}

As representações trazidas nos livros de Eva Mills, de si e das demais mulheres que a autora trouxe à cena, presumem uma mesma mulher. Em seus recortes: mulheres que desejam mudanças, e mudam; mulheres que são mães, mas sem precisar perder o direito ao estudo e à vida pública por conta disso; mulheres independentes e com ações no espaço público; mulheres trabalhadoras, de ação e de escolhas.

Sua autobiografia é de uma mulher que conquistou um lugar de liderança e visibilidade por meio da educação no campo religioso protestante. Essa representação de si também esteve presente nas representações das outras mulheres, na configuração que Mills escolheu representálas, mesmo que algumas não tivessem tido as mesmas oportunidades que ela.

Quando Eva Mills constrói sua identidade a partir de outras biografias, pondo outros em perspectiva, não o faz apenas para se construir na relação com esse outro, mas também para construir duas identidades em uma: a sua e a do outro. Ao construir a identidade desse outro, corrobora em sua própria identidade, agregando elementos para a produção de um discurso de grupo, a partir do qual ela constrói seu nome próprio (LEJEUNE, 2008) e uma identidade para esse mesmo grupo, por meio de uma memória que não é só sua, mas de uma coletividade.

Nesse grupo de três pequenos livros, escritos por uma missionária protestante sobre seu trabalho no Brasil, encontramos o desenrolar de um processo de construção de identidade de uma professora, produzida em íntima relação com as exigências de seu grupo de pertencimento, tanto no tempo dos fatos memorados quanto no tempo da escrita memorialística. Nessas obras, a evidência de um único projeto autobiográfico, em que a autora-narradora-personagem se evidencia em diferentes papéis, postulados nas relações de gênero de seu tempo. Uma construção de si, um espelho a se ver no outro.

\footnotetext{
30 "De um lado sobressai o apelo à natureza feminina voltada para o cuidado e a guarda natural da criança; assim, o instinto maternal da mulher é o argumento para justificar a sua incorporação nesse campo de trabalho; por outro [...] a necessidade de suprir trabalhadores em larga escala para uma atividade pouco atrativa" (SOUZA, 1998, p. 63).
}

Práxis Educativa, Ponta Grossa, v. 14, n. 3, p. 915-937, set./dez. 2019 Disponível em: < http://www.revistas2.uepg.br/index.php/praxiseducativa> 
As muitas Evas de uma história: a produção de um lugar a partir da publicação de autobiografias...

\section{Referências}

BEAUVOIR, S. O segundo sexo: a experiência vivida. 4. ed. São Paulo: Difusão Europeia do Livro, 1980.

BOSI, E. Memória e sociedade: lembranças dos velhos. 11. ed. São Paulo: Companhia das Letras, 2004.

BOURDIEU, P. A ilusão biográfica. In: BOURDIEU, P. Razões práticas: sobre a teoria da ação. Campinas: Papirus, 1996. p. 74-82.

CASTILLO GÓMEZ, A. Historia de la cultura escrita: ideas para el debate. Revista Brasileira de História da Educação, Maringá, n. 5, p. 93-124, jan./jun. 2003.

CHAMON, C. S. Maria Guilhermina Loureiro de Andrade e a educação como missão. In: CONGRESSO INTERNACIONAL SOBRE PESQUISA (AUTO)BIOGRÁFICA, 2., 2006, Salvador. Anais... Salvador: Universidade do estado da Bahia, 2006.

CHAMON, C. S. Maria Guilhermina Loureiro de Andrade: a trajetória profissional de uma educadora (1869/1913). 2005. 338 f. Tese (Doutorado em Educação) - Universidade Federal de Minas Gerais, Belo Horizonte, 2005.

CHARTIER, R. A história cultural, entre práticas e representações. Rio de Janeiro: Bertrand Brasil, 1990.

ELIAS, N. O processo civilizador. Volume 1. Rio de Janeiro: Jorge Zahar, 1994.

HILSDORF, M. L. S. Educadoras metodistas no século XIX: uma abordagem do ponto de vista da História da Educação. Revista do Cogeime, São Paulo, v. 2, p. 93-98, jun. 2002.

HILSDORF, M. L. S. Francisco Rangel Pestana, jornalista, político, educador. 1986. 91 f. Tese (Doutorado em Educação) - Universidade de São Paulo, São Paulo, 1986.

LEJEUNE, P. O pacto autobiográfico: de Rousseau à internet. Belo Horizonte: UFMG, 2008.

MESQUIDA, P. Um destino manifesto: a presença de mulheres missionárias metodistas na educação brasileira. In: VIEIRA C. R. A.; NASCIMENTO, E. F. V. C. (Orgs.). Contribuições do Protestantismo para a história da educação no Brasil e em Portugal. Piracicaba: Unimep, 2016. p. 185-207.

MESQUIDA, P.; FERREIRA, J. B. M. Uma escola norte-americana de língua alemã em Curitiba: Ellen White e o Colégio Internacional, 1896-1904. In: MIGUEL, M. E. B.; FERREIRA, J. de L. (Orgs.). Formação de professores: história, políticas educacionais e práticas pedagógicas. Curitiba: Appris, 2015. p. 93-107.

MIGNOT, A. C. V. Baú de memórias, bastidores de histórias: o legado pioneiro de Armanda Álvaro Alberto. Bragança Paulista: Editora da Universidade de São Francisco, 2002.

Mignot, A. C. V.; CUNHA, M. T. S. (Orgs.). Práticas de memória docente. São Paulo: Cortez, 2003. 
MILLS, E. 8:28. Lancaster: Brookshire Publications, 1976.

MILLS, E. Em lugar do espinheiro. Belém: Missão Cristã Evangélica do Brasil, 1982.

MILLS, E. Stories from parakeet country. Lancaster: UFM International, 1986.

NASCIMENTO, E. F. C. Educar, curar, salvar: uma ilha de civilização no Brasil tropical. Maceió: Editora da Universidade Federal de Alagoas, 2007.

PALLARES-BURKE, M. L. G. Nísia Floresta, o carapuceiro e outros ensaios de tradução cultural. São Paulo: Hucitec, 1996.

PERROT, M. Minha história das mulheres. 2. ed. São Paulo: Contexto, 2016.

POLLAK, M. Memória e identidade social. Estudos Históricos, Rio de Janeiro, v. 5, n. 10, p. 200-212, 1992.

SEIGUER, P. Mujeres en tránsito, vidas en movimiento. In: SILVA, A. L. da; ORLANDO, E. de A.; DANTAS, M. J. (Orgs.). Mulheres em trânsito: intercâmbios, formação docente, circulação de saberes e práticas pedagógicas. Curitiba: CRV, 2015. p. 33-52.

SILVA, A. L. da. Narrativas de vida de ex-escravos como fonte/objeto para a história da educação. In: VASCONCELOS, M. C. C.; CORDEIRO, V. M. R.; VICENTE, P. P. (Orgs.). (Auto)biografia, literatura e história. Curitiba: CVR, 2014. p. 129-145.

SILVA, E. da. As mulheres protestantes: educação e sociabilidades. Revista Brasileira de

História das Religiões, Maringá, v. 7, n. 21, p. 161-190, jan./abr. 2015. DOI: https://doi.org/10.4025/rbhranpuh.v7i21.26581

SILVA, E. da. Cidadãos de outra pátria: anglicanos e batistas na Bahia. 1998. 444 f. Tese (Doutorado em História Social) - Universidade de São Paulo, São Paulo, 1998.

SOUZA, E. C.; PASsEGGI, M. da C. Apresentação. [Dossiê (Auto)biografia e educação: pesquisa e práticas de formação]. Educação em Revista, Belo Horizonte, v. 27, n. 1, p. 327-332, abr. 2011. DOI: https://doi.org/10.1590/s0102-46982011000100014

SOUZA, R. de F. de. Templos de civilização: a implantação da escola primária graduada no estado de São Paulo (1810-1910). São Paulo: Fundação Editora da Unesp, 1998.

VERAS, L. A. C. S. Memórias da Terra de Beulá: a construção de uma vida e produção de um lugar nas autobiografias de Eva Mills. 2017. 191 f. Dissertação (Mestrado em Educação) Pontifícia Universidade Católica do Paraná, Curitiba, 2017. 